\title{
Modelling the efficiency of power system with reserve capacity from variable renewable sources of energy
}

\author{
Alla E. Denysova ${ }^{1)}$ \\ ORCID: https://orcid.org/0000-0002-3906-3960; alladenusova@gmail.com. Scopus ID: 57193405766 \\ Vladimir R. Nikulshin ${ }^{1)}$ \\ ORCID: https://orcid.org/0000-0001-5946-8562; vnikul@ paco.net. Scopus ID: 6505787670 \\ Victor V. Wysochin ${ }^{1)}$ \\ ORCID: https://orcid.org/0000-0003-2279-203X; vvwin.od@gmail.com \\ Oksana S. Zhaivoron ${ }^{1)}$ \\ ORCID: https://orcid.org/0000-0001-6750-2388; jaivoron.oksana@ gmail.com \\ Yana V. Solomentseva ${ }^{1)}$ \\ ORCID: https://orcid.org/0000-0003-2279-7953; solomenceva73@gmail.com \\ 1) Odessa National Polytechnic University, 1, Shevchenko Ave. Odessa, 65044, Ukraine
}

\begin{abstract}
The paper considers modeling the efficiency of power system with integration large share of variable renewable sources of energy with the account of climate conditions of Ukraine. The proposed methodology with its position between system planning and dispatch simulation contributes to the field of hybrid energy system models. The idea behind the method allows high spatial and temporal resolution as well as the inclusion of the technical details of the power system and its dispatch. The novelty of this method is the usage of a parametric approach is chosen to analyze different variable renewable sources of energy scenarios, precisely every possible its share and mix. This provides insights on the systematic effects of different resource mixes and may serve as a new approach to the analysis of future power system development. The additional novelty aspect allows the optimization of the design of the technical details of the power system with large variable renewable sources shares to have continuous improvement of its energy efficiency. The energy balance model generator is well suited for the analysis of large share of variable renewable sources integration in the power system. The design of technical details of the power system with large variable renewable sources shares was optimized with the energy balance model. The results of numerical modelling demonstrated that at $80 \%$ variable renewable sources of energy share, the overproduction is reduced to $20 \%$, down from over $100 \%$ without grid extensions. With it, the necessary wind and solar capacity decreases. Consequently, the possible achievable variable renewable sources of energy share are increased, assuming the same technical potential. According to the results, a Ukrainian grid would allow to increase the possible variable renewable sources of energy share from $50 \%$ to $75 \%$.
\end{abstract}

Keywords: Efficiency; power system; dispatch; reliability; variable renewable sources of energy; energy balance model

For citation: Denysova A. E., Nikulshin V. R., Wysochin V. V., Zhaivoron O. S., Solomentseva Ya. V. Modelling the efficiency of power system with reserve capacity from variable renewable sources of energy. Herald of Advanced Information Technology. 2021; Vol. 4 No. 4:318-328. DOI: https://doi.org/10.15276/hait.04.2021.3

\section{INTRODUCTION, FORMULATION OF THE PROBLEM}

Sustainability, climate change, increasing cost of fossil fuels and a political imperative for energy independence have combined to increase interest in the use of renewable energy sources to meet growing electricity demands, as well partially displacing existing thermal power generation. Current power systems are still dominated by fossil fuel-based electricity generation and operated on supply following the changing demand. In such systems nuclear and coal plants usually operate as base load power plants, while other types of power plants, such as hydro and natural gas, balance the variability on the demand side. The increasing use of

(c) Denysova, A., Nikulshin, V., Wysochin, V.,

Zhaivoron O. S., Solomentseva Ya. V., 2021 renewable energy resources add additional complexity to power systems and makes them more challenging to operate, as shown in Fig. 1.

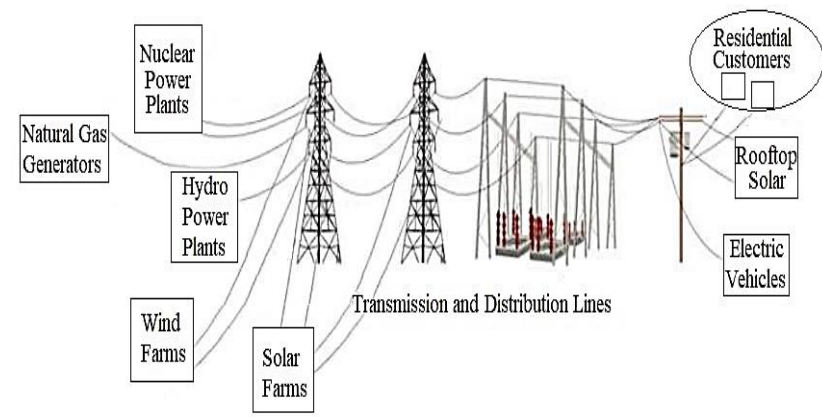

Fig. 1. Base and balance load power systems Source: compiled by the authors

To combat global warming and to address the fossil fuel scarcity, a shift to less carbon intensive resources in energy supply is necessary [1].

This is an open access article under the CC BY license (http://creativecommons.org/licenses/by/3.0) 
The power sector plays a central role in the decarbonization of the energy sector. Today, more than $40 \%$ of energy-related carbon emissions stem from the power sector [2].

Furthermore, the final energy carrier electricity is widely applicable and can thus contribute to the decarbonization of other sectors such as the residential, industry or transport sector. Finally, the power sector offers the possibility to efficiently use renewable energies and therewith provide carbon free electricity from non-exhaustible resources. Already today, the majority of renewable energy deployment takes place in the power sector and the observed learning and growth rates suggest that the share of renewable energies in electricity supply will continue to rise steeply [3]. Especially in Ukraine, where ambitious greenhouse gas emission reduction targets have been legislated, renewable energies play a key role. Wind and solar energy are bound to be the most important sources, due to their large potential in Ukraine [4], the observed growth rates, but also the existing support schemes [5].

Solar and wind generators, however, are not just another type of power plant that is set to replace other means of generation. They are called therefore Variable Renewable Energy Sources (VREs) in the following.

They differ from conventional, i.e., thermal dispatchable, generation in at least three respects:

- first, generation from wind and sun fluctuates: the temporal availability of wind and solar energy is driven by the meteorological conditions, such as the momentary wind speed or solar irradiation [6];

- second, wind and solar supply is not spread uniformly over Ukraine: regions with high meteorological potential for renewable generation are dispersed. Above all, they are not aligned with load centers, as the bulk of today's power generation is;

- third, generation from wind and solar energy has no fuel costs.

This can be challenging for electricity markets, where market prices are mostly driven by the marginal costs of generation, being the fuel costs of conventional power plants. The inclusion of fluctuating generation with low marginal costs can affect the prices significantly. The integration of VREs in the power sector thus entails important challenges [7]. On the technical system side, the temporal and regional variability of the resources may not be compatible with the current system operation and design. Also, on the market side, the influence of fluctuating generation at low marginal costs challenges current electricity markets.

The growing contribution of VREs in power supply, promoted by national support policies and the global goal to strongly curb its greenhouse gas emissions [8], suggests that adaption measures may be needed in the power system in the years to come. On top of that, the political goal of coupling Ukraine electricity markets also points to changes in the system. Power markets shall be linked more closely to facilitate international electricity trade, which implies additional cross border flows [9]. Therefore, Ukraine has launched innovative energy-efficient technologies to mitigate the effects of climate change effects, including renewable energy sources, as well as developed engineering system equipment for the energy supply of the housing and communal services. Architectural and construction solutions have been optimized, making it possible to reduce the use of energy resources and resulting greenhouse gas emissions.

The publication of forecasts ten years later showed that in Ukraine the increase in the average surface temperature in the period during 1900-2000 was $0.4 \ldots 0.6{ }^{\circ} \mathrm{C}$, and by region: north-east about $1^{\circ} \mathrm{C}$, woodland and forest-steppe $-0.7 \ldots 0.9^{\circ} \mathrm{C}$, steppe $-0.2 \ldots 0.3^{\circ} \mathrm{C}$. By seasons: in winter $-1.2^{\circ} \mathrm{C}$, in spring $-0.8^{\circ} \mathrm{C}$, in summer $-0.2 \ldots 0.3^{\circ} \mathrm{C}$. A negative trend in the number of frosty days and climate de-continentalization were detected. Predictive estimates of changes in the average surface temperature in Ukraine by 2050 are reduced to the fact that the increase will be $1.5 \ldots 2.0^{\circ} \mathrm{C}$, and in January for the south $-2.0^{\circ} \mathrm{C}$, for the north $-2.8^{\circ} \mathrm{C}$ and in July for Ukraine $-0.5-1.0^{\circ} \mathrm{C}[6]$

The displacement of fossil fuels by VREs is considered to be a viable option for mitigating greenhouse gas emissions. However, compared with conventional power-generating facilities, VREs have challenging operating characteristics such as lower and more variable capacity factors and variable, intermittent availability.

Superimposing demand and supply shows periods of both energy deficit and energy surplus

(Fig. 2). The traditional approach to making up for the energy deficit would be supply-side management by providing reserve capacity from other energy sources. However, the additional cost and infrastructure required could offset the economic and environmental benefits of utilizing VREs.

Following the above described problems:

- first, the role of transmission grid extensions for VRE integration must be analyzed.

- second, adapting electricity demand to the VRE supply via the coupling of the power sector to the heat power sector must be analyzed for the example of Ukraine as alternative VREs integration measure.

Both measures are evaluated with respect to their contribution to the technical system integration and 
the market integration of VREs. Therefore, it would be useful to use in the field of creating the technical adaption of the power system design to efficiently integrate large shares of VRE-system integration for generation.

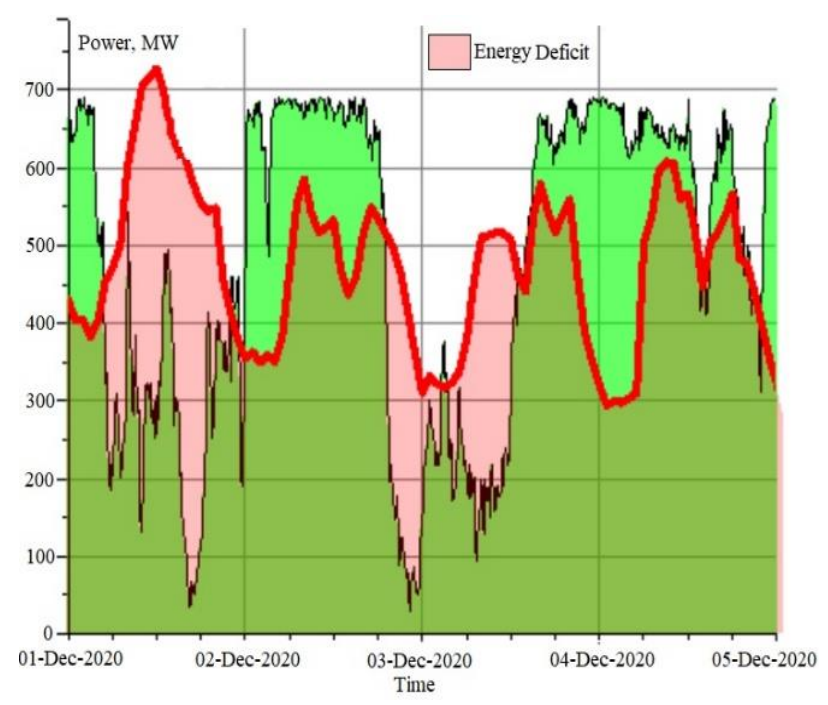

Fig. 2. Reserve capacity from VREs Source: compiled by the authors

System integration measures refer to all infrastructure measures, which facilitate system reliability and cost effectiveness in the presence of high VRE shares [11]. Overproduction should be avoided and the maximal residual load, i.e., necessary peak capacity of conventional power plants, reduced. Furthermore, the fast changes in residual load should be reduced or followed by the power system.

The major infrastructure measures available for VRE system integration are:

- grid extensions to connect remote sites of high VRE potential;

- additional storage capacity to balance VRE supply and demand;

- more flexible demand, via demand side management shifting demand to periods with high VRE supply.

- more flexible power plants that can adjust to VRE supply quickly.

Thus, the purpose of this study is to analyses the effects of large shares of VREs on the Ukrainian power systems and evaluates two VRE system integration measures.

\section{LITERATURE REVIEW}

To accommodate high shares of VREs in power supply systems, integration measures are necessary. To evaluate VRE system integration measures a mathematical model of the energy system is required.

Model features. Modeling energy systems with a large share of renewable energies requires high spatial resolution to account for regionally differing potential, as well as high temporal resolution to capture the short-term fluctuations, especially those of VREs. For the evaluation of the VREs integration measures, the relevant technical and economic properties of these measures need to be included. To take into account the long-term development and path dependency of investments, for example in power grid or plants, time frames of several decades would need to be included in the analysis. Due to the large size of the problem, a linear approach is taken, i.e., all system properties are described with linear equations. Linear programming is a powerful approach for large optimization problems and standard solver algorithms can be applied [12].

The mathematical, standard formulation of a linear optimization problem is

$$
\min c^{T} x \text { with } A x=b \quad x \geq 0,
$$

$x$ are the variables to be determined by the optimization, $c, b$ and $A$ are exogeneous parameters. The boundary conditions $A x=b$ and $x \geq 0$ define the feasible solution space. Many energy system models can be written in this form. Numerous algorithms to efficiently solve the above defined linear program, i.e., to find the minimum of the objective function in the allowed solution space, have been developed in the field of mathematical optimization. The solvation is based on the simplex algorithm. This algorithm takes advantage of the fact, that the optimal solution of a linear problem is always located at a vertex of the feasible region. The simplex algorithm therefore evaluates the value and the gradient of objective function at a starting vertex. Based on the gradient, the next vertex is chosen and the procedure is repeated until the optimal solution is found. With this iterative method, the algorithm approaches the global optimum [12, 13].

Optimization theory shows in the "duality principle", that every optimization problem has a dual problem. It states that, if the primal or dual problem has an optimal solution, the corresponding problem has an optimal solution as well. Furthermore, the solutions of the dual and the primal problem are identical.

For the above defined primal problems, the dual problem is

$$
\max b^{T} w \text { with } A^{T} w \leq c .
$$

It can be shown that the dual solution w corresponds to the derivative of the primal objective function with respect to the corresponding boundary condition [13].

The economic interpretation of the dual solution is of importance: if the objective function is a cost function, the dual variables are the marginal 
costs. They quantify by how much the total costs would change if the respective boundary condition was relaxed by one unit.

Energy Balance model. The Energy Balance model (EBM) is based on linear optimization [13]. Total system costs are minimized under a set of boundary conditions, which describe the behavior of the energy system. The system properties are characterized by the input parameters. As model results, cost-optimal capacity extension and dispatch of generation, transmission and storage units are computed. Furthermore, total costs, as well as overall emissions result from the model. The marginal costs of energy generation are used as indicators for energy prices. The model generator allows to realize high spatial and temporal resolution. The driver of the model is the energy demand.

A given demand for an energy commodity com has to be met in every time step $t$ and model region $x$ :

$$
\operatorname{supply}(\operatorname{com}, \mathrm{x}, \mathrm{t}) \geq \operatorname{demand}(\operatorname{com}, \mathrm{x}, \mathrm{t}) \text {. }
$$

This equation ensures the energy balance and is the most important boundary condition to the cost optimization, as it drives the energy supply. The EBM generator is applied to the power sector, i.e., the electricity load has to be satisfied. However, the Energy Balance model can also be applied to any other commodities. The energy balance needs to be respected in every model time step and region, reflecting the regionally and temporally resolved analysis of the energy system.

The other boundary equations describe the technical properties of the energy system. They can be classified in three groups. The first group includes the equations describing the generation processes, such as power plants, heat generation plants, etc. Energy storage is described in a second group of equations and commodity transport, for example, electricity transmission, in a third.

All of these boundary conditions have to be respected for every time step and region and define the possibilities to supply the demand. Other restrictions concerning several technologies can be included as well, such as emission constraints or minimal shares of renewable energy supply. The model computes the cost-optimal solution to supply the demand, under these boundary conditions.

The objective function $z$ of the optimization is the total cost function. It consists of three parts. For capacity additions of generation, storage or transport units, the investment costs $K^{i n v}$ have to be taken into account. Fixed operation and maintenance costs $K^{f i x}$ occur for all, new and old capacities.
The third part includes the variable costs $K^{v a r}$, such as fuel costs $(\mathrm{F})$, variable operation $(\mathrm{O})$ and maintains (M) costs and costs for emission allowances $(\mathrm{Em})$ :

$$
\begin{aligned}
& \mathrm{z}=\mathrm{K}^{\mathrm{inv}}+\mathrm{K}^{\mathrm{fix}}+\mathrm{K}^{\mathrm{var}}, \\
& \mathrm{K}^{\mathrm{inv}} \propto \text { capasity additions, } \\
& \mathrm{K}^{\mathrm{fix}} \propto \text { all installed capasity, } \\
& \mathrm{K}^{\mathrm{var}} \propto \text { cenergy supplied. }
\end{aligned}
$$

The dual variable to the condition guaranteeing that demand is met in the EBM equation gives the increase in costs if unit more was to be produced.

These marginal costs of energy can be interpreted as wholesale price of the commodity [16]:

$$
\begin{aligned}
& \mathrm{d}(\text { com, } \mathrm{x}, \mathrm{t}) \leq \\
& \sum_{\mathrm{p} \in \mathrm{P}}\left[\sum_{\text {com }^{\text {in }}} \mathrm{E}^{\text {out }}\left(\mathrm{p}, \mathrm{com}^{\text {in }}, \text { com } \mathrm{x}, \mathrm{t}\right)-\right. \\
& \left(E^{\text {in }}\left(p, c^{\text {out }}, \text { com, } x, t\right)\right]+ \\
& \sum_{\text {steSt }}\left[\mathrm{ESt}^{\text {out }}(\text { st, com, } \mathrm{x}, \mathrm{t})-\right. \\
& \left.\mathrm{ESt}^{\mathrm{in}}(\mathrm{st}, \mathrm{com}, \mathrm{x}, \mathrm{t})\right]+ \\
& \underset{\substack{x^{\prime} \in \mathbb{N}(x) \\
g \in G}}{\forall \operatorname{com}^{\prime} \in \mathrm{Com}^{\text {de }},}
\end{aligned}
$$

where: $\mathrm{d} \quad-$ commodity demand; com, com $^{\text {in }}$, com ${ }^{\text {out }}$ - commodities; $p \in P$ - generation process type; $\mathrm{x} \in \mathrm{X}-$ model regions; $\mathrm{t} \in \mathrm{T}-$ modeled time steps; st $\in \mathrm{St}$ - storage type; $\mathrm{F}^{\mathrm{imp}}$ import; $F^{\exp }$ - export; ESt ${ }^{\text {in }}$ - storage input; $\mathrm{ESt}^{\text {out }}$ - storage output; $E^{\text {out }}$ - generation; $E^{\text {in }}$ - usage of demanded commodities, $\mathrm{E}^{\text {in }}$ have to be subtracted in the balance.

This optimization is performed based on exogenous input parameters specifying the characteristics of the analyzed system. The total costs are computed based on the specific generation, storage and transport cost and hence the costs assumptions are crucial for cost optimization. Another input is the load curve. For each region and time step the load level has to be provided to the model. Also, the temporal and regional availability of some resources, such as VREs, is taken into account via the input of respective time series. Finally, the existing infrastructure and limits to its extensions are exogenous to the model. Generation infrastructure extension for example can be restricted by the technical potential for renewable deployment, but also by political circumstances, for example, for nuclear power plants in Ukraine. Depending on the mode of operation, the model can provide different results and insights. The EBM can be used as simulation tool or for infrastructure planning. The capacity extension can be disabled setting the upper limits for capacity extensions to current or exogenously defined capacities. In this simulation mode, the model determines cost- 
optimal capacity dispatch to supply the demand. On demand, i.e., relaxing the upper bounds for capacity expansion, it also computes cost-optimal extensions of the power plant, storage and transport infrastructure and is thus used as system planning tool. Partly relaxation of the capacity extension bounds, allows for compromises between these two operation modes. For example, only grid extensions can be computed, based on the regional cost-optimal capacity dispatch of generation and storage units. Three elements, model input, model equations and the model results exist for every model region or every connection between regions.

Model formulation. This section describes the mathematical implementation of the linear optimization. The three groups of boundary conditions are introduced consecutively, followed by the energy balance. Energy balance model for generation processes is shown in Fig. 3.
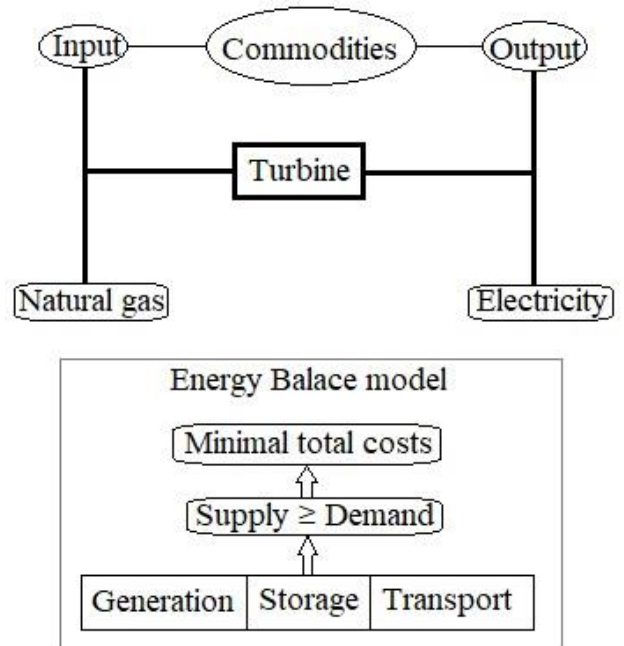

Fig. 3. EBM generation processes

Source: compiled by the authors

Finally, the cost function is defined:

$$
\begin{gathered}
\mathrm{E}_{\mathrm{i}}^{\text {out }}\left(\mathrm{p}_{\mathrm{i}}, \operatorname{com}_{\mathrm{i}}^{\text {in }}, \operatorname{com}_{\mathrm{i}}^{\text {out }}, \mathrm{x}_{\mathrm{i}}, \mathrm{t}\right)= \\
\eta_{\mathrm{i}}\left(\mathrm{p}_{\mathrm{i}}, \operatorname{com}_{\mathrm{i}}^{\text {in }}, \operatorname{com}_{\mathrm{i}}^{\text {out }}, \mathrm{x}_{\mathrm{i}}\right) \cdot \\
\mathrm{E}_{\mathrm{i}}^{\text {in }}\left(\mathrm{p}_{\mathrm{i}}, \operatorname{com}_{\mathrm{i}}^{\text {out }}, \operatorname{com}_{\mathrm{i}}^{\text {in }}, \mathrm{x}, \mathrm{t}\right), \\
\mathrm{E}_{\mathrm{i}}^{\text {out }}(\mathrm{t})=\eta_{\mathrm{i}} \mathrm{E}_{\mathrm{i}}^{\mathrm{in}}(\mathrm{t}), \quad \forall_{\mathrm{i}} \in \mathrm{I}, \\
\mathrm{E}_{\mathrm{i}}^{\text {out }}(\mathrm{t}) \leq \mathrm{af}_{\mathrm{i}} \cdot \mathrm{C}_{\mathrm{i}}, \quad \forall_{\mathrm{i}} \in \mathrm{I}, \\
\mathrm{E}_{\mathrm{i}}^{\text {out }}(\mathrm{t})=\mathrm{cf}_{\mathrm{i}}(\mathrm{t}) \cdot \mathrm{af}_{\mathrm{i}} \cdot \mathrm{C}_{\mathrm{i}}, \quad \forall_{\mathrm{i}} \in \mathrm{I}^{\text {vre }}, \\
\left|\mathrm{E}_{\mathrm{i}}^{\text {out }}(\mathrm{t})-\mathrm{E}_{\mathrm{i}}^{\text {out }}(\mathrm{t}-1)\right| \leq \tau_{\mathrm{i}} \cdot \mathrm{C}_{\mathrm{i}} \\
\forall_{\mathrm{i}} \in \mathrm{I} \backslash \mathrm{I}^{\text {vre }}, \quad, \quad \\
\mathrm{C}_{\mathrm{i}}=\mathrm{c}_{\mathrm{i}}^{0}+\mathrm{C}_{\mathrm{i}}^{\mathrm{N}}, \quad \forall_{\mathrm{i}} \in \mathrm{I}, \\
\mathrm{c}_{\mathrm{i}}^{\text {min }}=\mathrm{C}_{\mathrm{i}}+\mathrm{c}_{\mathrm{i}}^{\text {max }}, \quad \forall_{\mathrm{i}} \in \mathrm{I},
\end{gathered}
$$

where: variables: $E_{i}^{\text {in }}(t), E_{i}^{\text {out }}(t)$ - consumption (input \& output); $\mathrm{C}_{\mathrm{i}}-$ generation unit capacity;

parameters: $a_{i}-$ availability factor; $\eta_{i}-$ transformation efficiency; $\tau_{\mathrm{i}}$ - power change factor; $\mathrm{c}_{\mathrm{i}}^{0, \mathrm{~min}, \mathrm{max}}$ - installed, minimal \& maximal capacity; $c f_{i}(t)$ - capacity factor for VREs; $\mathrm{x} \in \mathrm{X}$ - model regions; $\mathrm{t} \in \mathrm{T}-$ model time steps; com, $\operatorname{com}^{\text {in }}, \operatorname{com}^{\text {out }} \in \mathrm{Com}-$ commodities; $\mathrm{Com}^{\mathrm{vre}} \subset$ Com - variable renewable commodities; $\mathrm{p} \in \mathrm{P}$ general process type.

All variables and parameters are positive. Capital letters denote variables, quantities determined by the model and small letters denote input parameters and sets. The above equations control the generation processes. They are valid for all model regions, time steps, commodities and transformation processes $\left(\forall \mathrm{x} \in \mathrm{X}, \forall \mathrm{t} \in \mathrm{T}, \forall \mathrm{com}^{\text {in }}\right.$, com $\left.^{\text {out }} \in \mathrm{C}_{0}, \quad \forall \mathrm{p} \in \mathrm{P}\right)$, if not noted differently.

\section{Model of complex conversion processes}

For EBM of complex conversion processes, the inclusion of longer process chains in the model can be necessary. To represent a gas-fired combined heat and power (CHP) production for example, at least three different process steps are necessary: first, natural gas is burned in the gas turbine. One part of the generated energy is transformed to electricity; the other part is used to generate useful heat. The energy generated from burning the natural gas can be understood as an additional, intermediate commodity, as can be seen in Fig. 4.

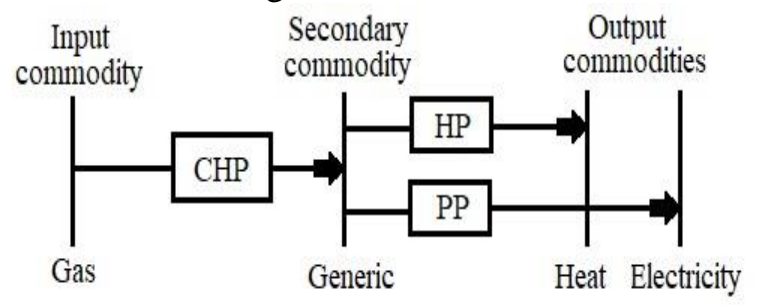

Fig.4. Commodity flows and chains for CHP:

CHP - the combined heat and power system;

HP - heat generation; $\mathbf{P P}$ - power production Source: compiled by the authors

The secondary commodity introduced in the reference energy system creates the link between the three involved commodities: natural gas, heat and electricity.

To respect energy conservation, an additional energy balance is introduced for the secondary commodities $\mathrm{C}_{0}{ }^{\mathrm{sec}}$ in equation:

$$
\begin{gathered}
\sum_{\mathrm{p}}\left[\sum_{\text {com }^{\text {in }}} \mathrm{E}^{\text {out }}\left(\mathrm{p}, \mathrm{com}^{\mathrm{in}}, \mathrm{com}, \mathrm{x}, \mathrm{t}\right)-\right. \\
\sum_{\text {com }^{\text {out }}\left(\mathrm{E}^{\text {in }}\left(\mathrm{p}, \mathrm{com}^{\text {out }}, \mathrm{com}, \mathrm{x}, \mathrm{t}\right)\right]+} \\
\sum_{\text {st }}\left[\mathrm{ESt}^{\text {out }}(\mathrm{st}, \mathrm{com}, \mathrm{x}, \mathrm{t})-\right. \\
\left.\mathrm{ESt}^{\text {in }}(\mathrm{st}, \mathrm{com}, \mathrm{x}, \mathrm{t})\right]+ \\
\sum_{\mathrm{g}, \mathrm{x}^{\prime} \in \mathrm{N}(\mathrm{x})}\left[\mathrm{F}^{\mathrm{imp}}\left(\mathrm{g}, \mathrm{com}, \mathrm{x}, \mathrm{x}^{\prime}, \mathrm{t}\right)-\right. \\
\left.\mathrm{F}^{\exp }\left(\mathrm{g}, \mathrm{com}, \mathrm{x}, \mathrm{x}^{\prime}, \mathrm{t}\right)\right] \geq 0, \forall \text { com } \in \mathrm{Com}^{\mathrm{sec}}
\end{gathered}
$$

This is in analogy to the energy balance for demand commodities in equation (17), except that demand for secondary commodities is zero. 


$$
\begin{aligned}
& \mathrm{d}(\operatorname{com}, \mathrm{x}, \mathrm{t}) \leq \\
& \sum_{\mathrm{p} \in \mathrm{P}}\left[\sum_{\text {com }^{\text {in }}} \mathrm{E}^{\text {out }}\left(\mathrm{p}, \mathrm{com}^{\mathrm{in}} \text {, com }, \mathrm{x}, \mathrm{t}\right)-\right. \\
& \sum_{\text {com }}{ }^{\text {out }}\left(\mathrm{E}^{\text {in }}\left(\mathrm{p}, \mathrm{com}^{\text {out }}, \mathrm{com}, \mathrm{x}, \mathrm{t}\right)\right]+ \\
& \sum_{\text {st } \in \text { St }}\left[\mathrm{ESt}^{\text {out }}(\mathrm{st}, \mathrm{com}, \mathrm{x}, \mathrm{t})-\right. \\
& \left.\mathrm{ESt}^{\mathrm{in}}(\mathrm{st}, \mathrm{com}, \mathrm{x}, \mathrm{t})\right]+ \\
& \sum_{\mathrm{x}^{\prime} \in \mathrm{N}(\mathrm{x})}\left[\mathrm{F}^{\mathrm{imp}}\left(\mathrm{g}, \mathrm{com}, \mathrm{X}, \mathrm{X}^{\prime}, \mathrm{t}\right)-\right. \\
& \mathrm{g} \in \mathrm{G} \\
& \left.\mathrm{F}^{\exp }\left(\mathrm{g}, \text { com }, \mathrm{x}, \mathrm{x}^{\prime}, \mathrm{t}\right)\right], \forall \text { com } \in \mathrm{Com}^{\mathrm{de}}
\end{aligned}
$$

All methods for some processes, the share between different input and output commodities needs to be restricted. In the case of CHP generation, the mix between heat and power production is set by the technical realization of the power plant.

\section{RESULTS OF NUMERICAL MODELLING FOR CONDITIONS OF UKRAINE}

The proposed method is based on the use of Ukrainian power sector. Choosing the model regions and time steps, a compromise between high resolution and a manageable size of the optimization problem has to be found.

Dependence of regions and time steps. In a lot of time steps, very similar problems will be solved, for example a windy afternoon in winter, an afternoon in autumn without wind or solar supply, or a sunny summer day. The following criteria reflecting the properties of the entire year, for example, weeks or days, are modeled to reduce the model size. Those representative periods are chosen according to the following criteria in order to closely reflect the properties of the entire year. Interconnection between regions: three supply commodities, ten generation processes, one storage and one grid technology are shown in graph (Fig. 5).

The input parameters to the model describe the current power system as:

- Numerical model setup. The EBM generator is applied to one typical year. However, modeling every hour of the year would result in large model size.

- Selection of representative time steps. In the temporal domain, hourly resolution is chosen. The size of above described EBM increases considerably with the number time steps and regions (Fig.5).

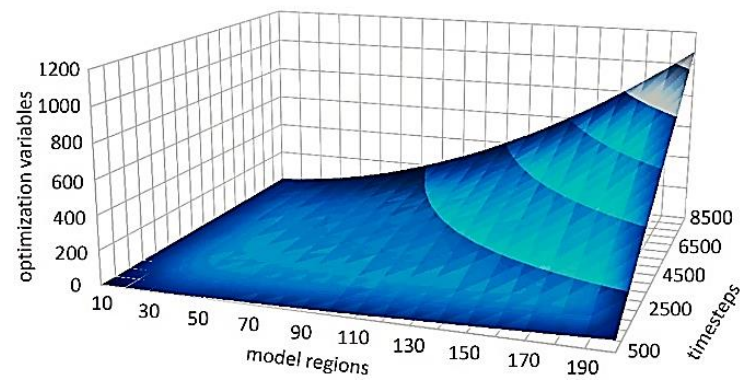

Fig. 5. Optimized variables dependence of regions and time steps

Source: compiled by the authors
Therefore, instead of modeling an entire year:

- the average residual load (RL) in the selected time steps should be close to the average annual RL;

- the selected time steps should include extreme values of RL;

- the seasonal cycle, daily cycle and ideally also weekly cycle of the year should be reflected in the representative time steps.

These criteria translate into an optimization problem, which allows to determine representative time steps.

Objective function: $\min \left[\overline{\Delta_{t}}-\overline{\triangle_{t}}\right]$, where $\Delta_{t}$ is the RL:

$$
\begin{aligned}
& \Delta_{\mathrm{t}} \sum_{\mathrm{x}}(\mathrm{d}(\text { com, } \mathrm{x}, \mathrm{t})- \\
& \left.\sum_{\mathrm{p}, \mathrm{com}^{\mathrm{in}} \in \mathrm{C}_{0}^{\text {vre }}} \mathrm{E}\left(\mathrm{p}, \mathrm{com}, \mathrm{com}^{\text {in }}, \mathrm{x}, \mathrm{t}\right)\right) \text {. }
\end{aligned}
$$

Boundary conditions include: period with minimal residual load; period with maximal residual load; select contiguous periods distribute representative periods equally over the year.

The optimization is solved via exhaustive search. First the periods with minimal and maximal residual load are identified. The remaining periods are then chosen such that the deviation of the average residual load of the selected time steps and the annual average is minimal. The solution of this optimization problem provides representative periods of the year, which can then be analyzed in the EBM model. As shown in [14] careful selection of the representative periods allows achieving better results: modeling few, carefully selected periods allows achieving similar results to a case where longer periods of the year are included in the model [15]. In our case six weeks are chosen. One-time steps thus stand for about eight hours of the year. The modeled time steps are weighted accordingly. The weighting is uniform. Depending on the share and mix of VREs in the analyzed scenarios, the representative weeks are different. The optimization can be applied to any commodity, i.e., the representative times steps can be chosen with respect to any residual load. The representative time steps are chosen with respect to the RL for electricity.

The recent forecast for warming in Ukraine for a number of periods up to 2100 is shown in Fig. 6. It is evident that the results of instrumental measurements of temperature rise and warming forecasts in Ukraine generally correspond to the trends of global temperature change, and Ukraine faces the same challenges and risks that the world is concerned about [17]. Adaptation of municipal energy to climate change will contribute to the economy and rational use of fuel and energy and material resources, reduce energy costs of the housing and communal sector, introduction of architectural, innovative en- 
gineering solutions and improvements in living standards, as well as reducing the country's dependence on imports of fuel and energy resources, and therefore will increase the country's energy security.

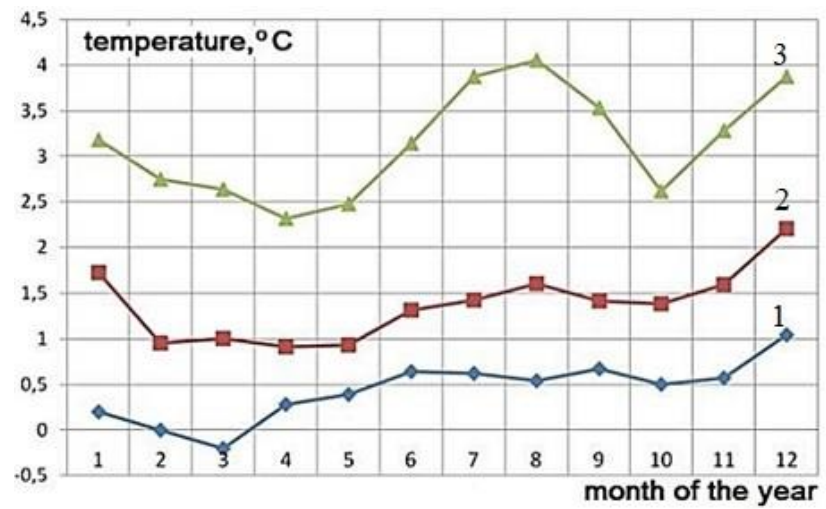

Fig. 6. Projections of changes in average monthly air temperatures in Ukraine [17]:

1 - 2011-2030 yrs. (average value $0.44^{\circ} \mathrm{C}$ );

$2-2031-2050$ yrs. (average value $1.57^{\circ} \mathrm{C}$ );

$3-2051-2100$ yrs. (average value $3.15^{\circ} \mathrm{C}$ )

Source: compiled by [17]

In the energy system of Ukraine in 2020, the share of wind power plants (WP) and solar power stations (PV) in the structure of electricity production has doubled - to $6.8 \%$ with a total electricity production of 148.9 billion $\mathrm{kWh}$. The installed capacity of these renewable power plants increased by $1.9 \mathrm{GW}$ during the year.

Increasing the installed capacity, primarily PV, given their stochastic nature of operation, significantly complicates the modes of operation of the power system. In 2020, electricity consumption decreased by $2.7 \%$ in three spring months, when PV energy production increases seasonally. The decrease in consumption at certain times of the day was $7 \%$.

The daily schedule of electricity consumption also changed:

- the difference between the minimum and maximum value of daily consumption capacity increased by an average of $300 \mathrm{MW}$, and in some months - by almost $600 \mathrm{MW}$;

- the level of electricity consumption during daytime hours decreased the most (for example, in May at 12:00 (in the hour of maximum PV load) the average consumption of working day decreased by 1.1 GW (from 16.1 to $15 \mathrm{GW}$ ). The peak of PV generation due to high solar activity occurs during the day, when the power system shows a decrease in consumption, compared with the morning and evening peaks. To maintain the balance in the power system and ensure operational safety during this period of the day, the dispatchers of the national power company "Ukrenergo" have to [18];

- apply all proposals of thermal power plant and hydroelectric power plant for unloading within the balancing market;

- issue operational safety commands to pump pumped-storage hydroelectricity to increase consumption.

If these measures are not enough, the limits of renewable power plants apply, the maximum total value of the limit was 2178.86 MW (June 7, 2020) (Fig.7.).

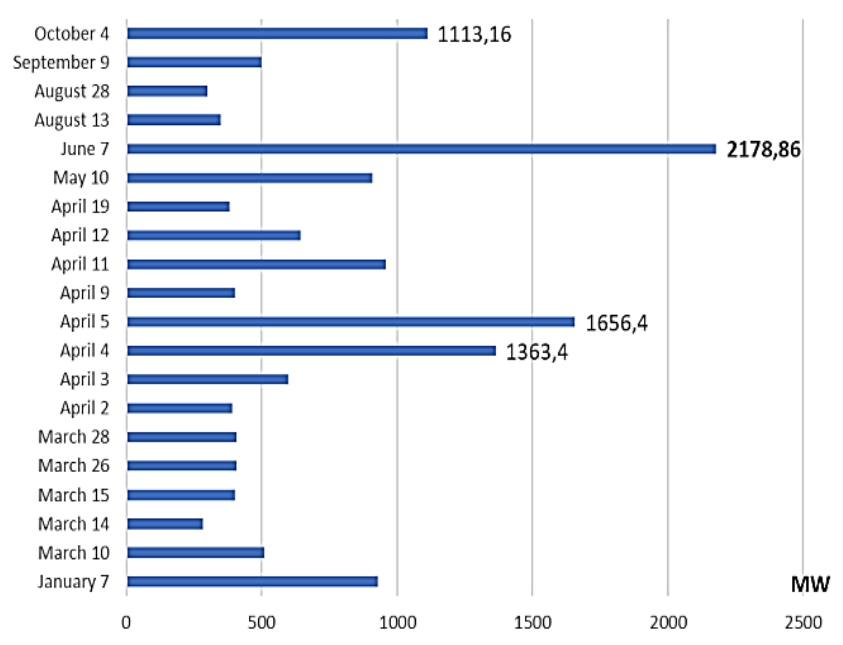

Fig. 7. Restrictions of VREs in the power system of Ukraine in 2020

Source: compiled by [18]

The balancing of renewable power plants, mainly PV, during the day and remains today the main problem of integration of renewable energy into the energy system of Ukraine. Therefore, there is a need to increase the flexibility of the power system with the intensive growth of the share of renewable energy in the generation structure, to avoid the need to limit electricity production WP and PV and ensure the safety and reliability of the power system. Therefore, highly maneuverable capacity and sufficient capacity reserves will allow to move to flexible energy management and operational security. Such technologies may include the use of Energy storage (ES) [19, 20]. To determine the possibilities of using ES, which can take part in adjusting demand for power. Consider a typical daily schedule of electricity consumption in the Integrated Power System of Ukraine and the generation of WP and PV. Taking into account the variability of renewable energy, we determine the areas in which ES can be used in the charge $(\mathrm{CHG})$ mode and recharge (RCHG) mode (Fig. 8) [18]. 


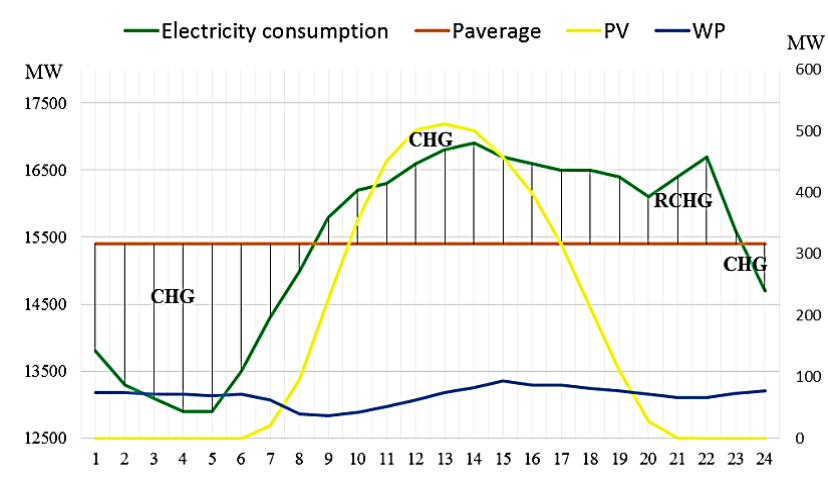

\section{Fig. 8. Electricity consumption, generation WP and PV typical summer day \\ Source: compiled by [18]}

The careful selection of representative periods, the coupling of the time series analysis to the optimization model and the deployment of several years of meteorological data all lead to considerable increase of robustness of the results.

Large shares of VREs lead to important challenges for the power system. The results of the parametric study quantify these challenges. First, if no VRE integration measures are taken, large excess electricity generation result. Overproduction rises steeply with VRE shares, from $10 \%$ of total load at VRE shares of $30 \%$ up to $60 \%$ at a share of $60 \%$. This is due to the low geographic and temporal correlation of VRE supply and load as well as the high temporal variability of VRE supply.

Due to the sampling of a large parameter space, the necessary VRE capacity to achieve any given VRE share can be quantified. It increases with overproduction and reaches up to 5 times the peak load for a VRE share of $75 \%$.

However, as the VRE capacity is limited by the technical potential for wind and solar generation, such high shares cannot be achieved, but only about $50 \%$. In terms of system adequacy, a challenging property of VREs is their low capacity credit, also caused by low geographic and temporal correlation of VRE supply and load.

The results show that, in the absence of a super grid, the capacity credit remains below $5 \%$ for most of the scenarios. As a consequence, large supplementary capacity is necessary.

A powerful Ukrainian grid smoothens the VRE supply, and this entails two major benefits for VRE integration, as the results show. First, overproduction is reduced.

At $80 \%$ VRE share, the computed overproduction is reduced to $20 \%$, down from over $100 \%$ without grid extensions. With it, the necessary wind and solar capacity decreases. Consequently, the pos- sible achievable VRE share is increased, assuming the same technical potential.

According to the results, a Ukrainian grid would allow to increase the possible VRE share from $60 \%$ to more than $85 \%$. Second, the average Ukrainian capacity credit of wind energy is increased from less than $5 \%$ to more than $10 \%$ for VRE shares with important contributions from wind energy.

\section{CONCLUSIONS}

The design of the technical details of the power system with large VRE shares has been optimized with the EBM generator. The methodology allows for high spatial and temporal resolution as well as the inclusion of the technical details of the power system and its dispatch. It is therewith well suited for the analysis of VRE integration in the power system. With its position between system planning and dispatch simulation, EBM contributes to the field of hybrid energy system models.

Instead, a parametric approach is chosen to analyze different VRE scenarios, precisely every possible VRE share and mix. This provides insights on the systematic effects of different resource mixes and may serve as a new approach to the analysis of future power system development.

However, as the VRE capacity is limited by the technical potential for wind and solar generation, such high shares cannot be achieved, but only about $50 \%$. In terms of system adequacy, a challenging property of VREs is their low capacity credit, also caused by low geographic and temporal correlation of VRE supply and load. The results show that, in the absence of a super grid, the capacity credit remains below $5 \%$ for most of the scenarios. As a consequence, large supplementary capacity is necessary.

A powerful Ukrainian overlay grid smoothens the VRE supply, and this entails two major benefits for VRE integration, as the results show. First, overproduction is reduced.

At $80 \%$ VRE share, the computed overproduction is reduced to $20 \%$, down from over $100 \%$ without grid extensions. With it, the necessary wind and solar capacity decreases. Consequently, the possible achievable VRE share is increased, assuming the same technical potential.

According to the results, a Ukrainian grid would allow to increase the possible VRE share from $50 \%$ to more than $75 \%$. Second, the average Ukrainian capacity credit of wind energy is increased from less than $5 \%$ to more than $10 \%$ for VRE shares with important contributions from wind energy. 


\section{REFERENCES}

1. Edenhofer, O., Pichs-Madruga. R., Sokona, Y., Seyboth, K., Matschoss, P., Kadner, S., Zwickel, T., Eickemeier, P., Hansen, G., Schlomer, S. \& Stechow, C. "Intergovernmental panel on climate change (IPCC)". IPCC Special Report on Renewable Energy Sources and Climate Change Mitigation. - Available from: https://www.ipcc.ch/site/assets/uploads/2018/03/SRREN_Full_Report.pdf. - [Accessed: 12th Oct 2020].

2. Intergovernmental panel on Climate Change (IPCC). "Summary for policymakers". IPCC, 2021. Leading authors: Masson-Delmotte, V., P. Zhai, A. Pirani, S. L. Connors, C. Péan, S. Berger, N. Caud, Y. Chen, L. Goldfarb, M. I. Gomis, M. Huang, K. Leitzell, E. Lonnoy, J.B.R. Matthews, T. K. Maycock, T. Waterfield, O. Yelekçi, R. Yu \& B. Zhou (eds.) Cambridge University. Press. In Press. - Available from: https://www.ipcc.ch/report/ar6/wg1/downloads/report/IPCC_AR6_WGI_Full_Report.pdf. - [Accessed: 12th Oct 2020].

3. Mitigation from a cross-sectoral perspective in climate change 2007. Lead Authors: B. Metz, O. R. Davidson, P. R. Bosch, R. Dave, L. A. Meyer (eds.) - Available from: https://www.ipcc.ch/site/assets/uploads/2018/02/ar4-wg3-chapter11-1.pdf. - [Accessed: 12th Oct 2020].

4. Iles, C. E. et al. "The benefits of increasing resolution in global and regional climate simulations for European climate extremes. Geoscientific model development". 2020;13(11): 5583-5607. DOI: https://doi.org/10.5194/gmd-13-5583-2020.

5. Jacob, D. et al. "Climate impacts in Europe under $+1.5^{\circ} \mathrm{C}$ global warming". Earth's Future. 2018. DOI: https://doi.org/10.1002/2017ef000710.

6. Lipinskiy, V. M. "Global climate change and its response in the dynamics of Ukraine's climate" [in Ukrainian]. Proceedings of the International Conference "Investment and Climate Change: Opportunities for Ukraine. Climate Change Investments. Kyiv: Ukraine. July 10-12 2002. p.177-185

7. Global Market Outlook 2019-2023. "Solar power Europe". 2019. - Available from: https://www.solarpowereurope.org/global-market-outlook-2021-2025/. - [Accessed: 12th Oct 2020].

8. European Commission. "A roadmap for moving to a competitive low carbon economy in 2050". Communication from the European Commission. 2011. 129 p. - Available from: http://ec.europa.eu/clima/documentation/roadmap/docs/com_2011_112_en.pdf. - [Accessed: 12th Oct 2020].

9. European Network of Transmission System Operators for Electricity (ENTSOE). Ten-Year Network Development Plan 2010-2020. ENTSO-E, 2012. - Available from: https://www.entsoe.eu/ fileadmin/user_upload/_library/SDC/TYNDP/2012/TYNDP_2012_report.pdf. - [Accessed: 12th Oct 2020].

10. "Increasing the climate resilience of the agricultural sector of the South of Ukraine". Szentendre, Hungary. Enhancing Climate Resilience in Agriculture in Southern Ukraine [in Ukrainian]. October, 2015.

11. Delucchi, M. A. \& Jacobson, M. Z. "Providing all global energy with wind, water and solar power". Part II: Reliability, system and transmission costs, and policies. Energy Policy. 2011; 39(3): 1170-1190, https://doi.org/10.1016/j.enpol.2010.11.045.

12. Papadimitriou, C. H. \& Steiglitz, K. "Combinatorial optimization: algorithms and complexity. Prentice-Hall, Englewood Cliffs. NJ: USA. 1982. ISBN: 0486402584, https://lib.ugent.be/catalog/rug01:000825070.

13. Pina, A., Silva, C. A. \& Ferrão, P. "High-resolution modeling framework for planning electricity systems with high penetration of renewable". Applied Energy. Publ. Elsevier. 2013; Vol. 112(C): 215-223. Available from: https://ideas.repec.org/a/eee/appene/v112y2013icp215-223.html. DOI: https://doi.org/ 10.1016/j.apenergy.2013.05.074.

14. Heitmann, N. "Solution of energy problems with the help of linear programming". Diplomathesis, Naturwissenschaftliche Fakultät der Universität Augsburg. 2005.

15. Heitmann, N. \& Hamacher, T. "Stochastic model of the German Electricity System". Energy Systems: Optimization in the Energy Industry. 2009; 3: 365-385.

16. Herrmann, J. "Optimierung der städtischen energieversorgung am beispiel der stadt augsburg unter besonderer berücksichtigung von wärmetransportmechanismen". $\mathrm{PhD}$ thesis, Mathematisch- 
Naturwissenschaftlichen Fakultät der Universität Augsburg. Max-Planck-Institut für Plasmaphysik, Garching. 2012.

17. Basok, B., Bazyeev, Y. \& Kuraieva, I. "Adaptation of municipal heat energy to climate change" [in Ukrainian]. Visn. Nac. Acad. Nauk Ukr. 2021; No. 4: 60-75. DOI: https://doi.org/10.15407/visn2021.04.060.

18. Veremiichuk, Y. \& Zamulko A. "The use of energy storage to control the electrical load of the power system Ukraine'. Proceedings of V International Scientific-Technical Conference "Actual problems of renewable energy, construction and environmental engineering". Kielce University of Technology. Kielce: Poland. 2021. p. 85-87. ISBN 978-83-66678-08-8.

19. Child, M., Breyer, C., Bogdanov, D. \& Hans-Jose Fell. "The role of storage technologies for the transition to a $100 \%$ renewable energy system in Ukraine". Energy Procedia. October 2017; Vol. 135: 410 423. DOI: https://doi.org/10.1016/j.egypro.2017.09.513.

20. Veremiichuk, Y., Yarmoliuk, O., Pustovyi, A., Mahnitko, A. \& Zicmane, Lomane, T. "Features of electricity distribution using energy storage in solar photovoltaic structure". Latvian Journal of Physics and Technical Sciences. 2020; Vol. 57 Issue 5: 18-29.

Conflicts of Interest: the authors declare no conflict of interest

Received 22.12.2020

Received after revision 27.02.2021

Accepted 14.03.2021

DOI: https://doi.org/10.15276/hait.04.2021.3

УДК 621.3:620.91:620.97

\title{
Моделювання ефективності енергетичних систем з резерву- ванням потужності за рахунок відновлювальних джерел енергії
}

\author{
Алла Євсіївна Денисова ${ }^{1)}$ \\ ORCID: https://orcid.org/0000-0002-3906-3960; alladenysova@gmail.com. Scopus ID: 57193405766 \\ Володимир Русланович Нікульшин ${ }^{1)}$ \\ ORCID: https://orcid.org/0000-0001-5946-8562; vnikul@ paco.net. Scopus ID: 6505787670 \\ Віктор Васильович Височин ${ }^{1)}$ \\ ORCID: https://orcid.org/0000-0003-2279-203X; vvwin.od@gmail.com \\ Оксана Сергіївна Жайворон ${ }^{1)}$ \\ ORCID: https://orcid.org/0000-0001-6750-2388; jaivoron.oksana@gmail.com \\ Яна Владиславівна Соломенцева ${ }^{1)}$ \\ ORCID: https://orcid.org/0000-0003-2279-7953; solomenceva73@gmail.com \\ 1) Одеський національний політехнічний університет, пр. Шевченка, 1. Одеса, 65044, Україна
}

\begin{abstract}
АНОТАЦІЯ
У цій статті основна увага приділяється моделюванню ефективності енергетичної системи, я яку інтегрується велика частка різних відновлювальних джерел енергії з урахуванням кліматичних даних. Запропонована методологія, яка базується на використанні моделі енергетичного балансу і відрізняється поєднанням системного планування і диспетчеризації, $є$ підставою для створення ефективних гібридних моделей енергетичних систем. Ідея методу міститься в узгодженні просторовочасових і технічних можливостей роботи системи з вимогами до диспетчеризації. Новизна цього методу полягає в тому, що для аналізу ефективності енергетичної системи використано параметричний підхід для обгрунтування часток використання відновлюваних джерел енергії. Такий системний підхід до урахування впливу різних комбінацій первинних енергоресурсів, можна вважати інноваційним підходом до аналізу перспектив розвитку енергосистеми. Додатковий аспект новизни запропонованого методу полягає в можливості оптимізації техніко-економічних параметрів енергосистеми, яка працює 3 великими частками використання різнорідних відновлювальних джерел з метою підвищення іiі енергоефективності. Модель енер-
\end{abstract}


гетичного балансу добре підходить для визначення змінних часток відновлюваних джерел, які інтегруються в енергосистему. Шляхом числового моделювання з використанням моделі енергетичного балансу визначені оптимальні технічні параметри енергосистеми, що працює з різнорідними відновлювальними джерелами. Результати чисельного моделювання свідчать про те, що енергосистема України дозволяє збільшити частку використання змінних відновлюваних джерел енергії з 50 до $75 \%$.

Ключові слова: ефективність; система живлення; відправка; надійність; змінні відновлювані джерела енергії; модель енергетичного балансу
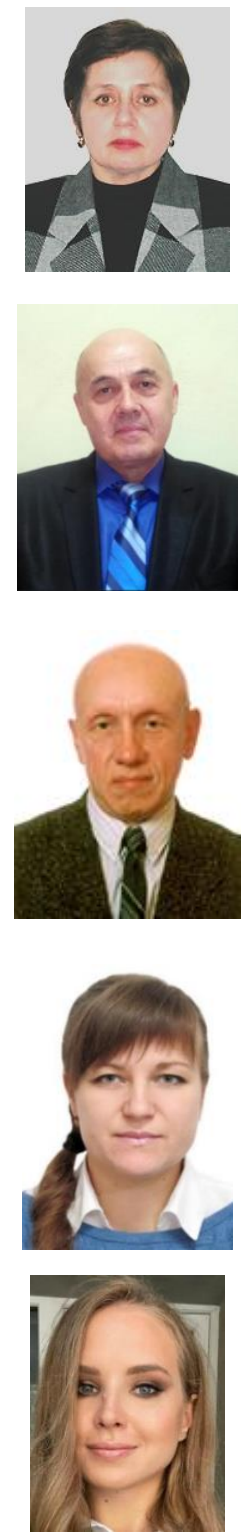

\section{ABOUT THE AUTHORS}

Alla E. Denysova - D.Sc. (Eng), Professor, Head of Ukrainian-Polish Institute. Odessa National Polytechnic University, 1, Shevchenko Ave. Odessa, 65044, Ukraine

ORCID: https://orcid.org/0000-0002-3906-3960; alladenysova@gmail.com. Scopus Author ID: 57193405766 Research field: Integrated energy saving technology; energy complexes and systems with renewable sources of energy

Алла Євсіївна Денисова - доктор технічних наук, професор, директор Українсько-польського інституту. Одеський національний політехнічний університет, пр. Шевченка, 1. Одеса, 65044,Україна

Vladimir R. Nikulshin - D.Sc. (Eng), Professor, Head of the Department of General Theoretical and Nontraditional Sources of Energy. Odessa National Polytechnic University, 1, Shevchenko Ave. Odessa, 65044, Ukraine ORCID: https://orcid.org/0000-0001-5946-8562; vnikul@paco.net. Scopus Author ID:6505787670 Research field: Thermodynamics; energy complexes and systems with renewable sources of energy

Володимир Р. Нікульшин - доктор технічних наук, професор, завідувач кафедри Загальної, теоретичної та нетрадиційної енергетики. Одеський національний політехнічний університет, пр. Шевченка, 1. Одеса, 65044, Україна

Victor V. Wysochin - Candidate of Engineering Sciences, Associate Prof. of the Department of General Theoretical and Nontraditional Sources of Energy. Odessa National Polytechnic University, 1, Shevchenko Ave. Odessa, 65044, Ukraine

ORCID: https://orcid.org/0000-0003-2279-203X; vvwin.od@gmail.com

Research field: Renewable sources of energy; energy complexes and systems with renewable sources of energy

Віктор Васильович Височин - кандидат технічних наук, доцент кафедри Загальної, теоретичної та нетрадиційної енергетики. Одеський національний політехнічний університет, пр. Шевченка, 1. Одеса, 65044,Україна

Oksana S. Zhaivoron - Postgraduate student of the Department of Thermal Power Plants and Energy Saving Technology. Odessa National Polytechnic University, 1, Shevchenko Ave. Odessa, 65044, Ukraine ORCID: https://orcid.org/0000-0001-6750-2388; jaivoron.oksana@gmail.com Research field: Thermal engines with renewable sources of energy

Оксана Сергіївна Жайворон - аспірант кафедри Теплових електричних станцій та енергозберігаючих технологій. Одеський національний політехнічний університет, пр. Шевченка, 1. Одеса, 65044,Україна

Yana V. Solomentseva - Postgraduate student of the Department of Thermal Power Plants and Energy Saving Technology. Odessa National Polytechnic University, 1, Shevchenko Ave. Odessa, 65044, Ukraine ORCID: https://orcid.org/0000-0003-2279-7953; solomenceva73@gmail.com Research field: Renewable sources of energy

Яна Владиславівна Соломенцева - аспірант кафедри Теплових електричних станцій та енергозберігаючих технологій. Одеський національний політехнічний університет, пр. Шевченка, 1. Одеса, 65044,Україна 